\title{
Implementation Strategy Smart Governance in Makassar City (Case Study on The Missing Capil Program for The Population and Civil Record)
}

\author{
Sri Wahyuni*, Alwi Alwi, Nur Indrayati Nur Indar
}

\begin{abstract}
Department of Public Administration, Universitas Hasanuddin, Indonesia *Corresponding author. Email: sri345396@gmail.com
\end{abstract}

\begin{abstract}
Smart City is a program that implements advances in technology and information in carrying out social life in a modern, efficient and effective manner. Smart City is applied in urban life by utilizing technology to realize smart living, smart governance, smart economy, smart environment, smart mobility, and the most important component, namely smart people. The focus of the study in this research is smart governance, where smart governance has implications for the use of the latest technology and information in carrying out policies in order to improve the competence of public services in the hope that their implementation is more efficient and better by looking at implementation strategies. Smart governance of three levels, namely the use of technology, vision, and collaboration. To answer the research questions used qualitative research approaches and methods with descriptive analysis. This study provides an overview of the results of the level of implementation of the strategy smart governance at the Makassar City Population and Civil Registry Office that has not been fully implemented optimally.
\end{abstract}

Keywords: Smart City, Smart Governance, Strategy, Implementation

\section{INTRODUCTION}

Along with the leap in science and technology as well as the concept of modern governance that is increasingly advanced, governments must take strategic steps to optimize their decision-making abilities and increase their level of social services by utilizing the facilities emerging technologies to develop smart government affairs. Studies deny the ability of state ICTs to radically change relations citizen- government in public affairs.

The development of smarter technology makes this smart concept not only for gadgets but can be used for a system or arrangement. The Smart City concept is part of this smart concept which is currently being discussed. The concept being discussed is services that are transparent and can make it easier for the public to get information correctly and it doesn't take a long time. The Smart City concept is also a present solution to improve resource management efficiently and effectively. The concept presented is a concept that is able to integrate easy access to information for city residents. [20]

In Indonesia, changes to the system-government have been published since 2001 as evidenced by the issuance of Instruction Presidential No. 6 of 2001 concerning the Development and Utilization of Telematics in Indonesia. The regulation describes government officials who must take advantage of the development and utilization of telematics to help sustain good governance and support the implementation of democratic governance. In addition to these regulations, the Government also issued called Instruksi Presiden No. 3 of 2003 about National Development Policies and Strategies $E$ government as evidence that the Indonesian government is serious about improving the system to provide improvements to public services to the community.

This smart city utilizes information technology in an efficient and effective community survival. Smart city is a city that utilizes the essence of smart 
living, smart government, smart economy, smart environment, smart mobility, and the most important thing in carrying it all out is smart people. [9]

The six indicators above are the basis for supporting Makassar City as a smart city. In terms of research, researchers focus on indicators smart governance, because smart governance a well-planned can be the main foundation in realizing implementation smart city. If smart governance is not implemented, the smart city will not be realized [19]. Therefore, smart governance is planned based on the guidelines and in accordance with the smart city concept and the planning planning concept that has been developed through the framework that has been created. Smart governance is the most important parameter in running a government that must have important aspects in it.

Smart Governance is a basic concept in improving governance by implementing the use and utilization of information technology that is integrated with the internet. The use of information technology can in fact help the government in order to improve participation in the world of politics, implement government programs, or complete public service facilities that have received less attention. The increasing participation of technology in its benefits to urban systems is making governments consider the role they should have in a knowledge-based society. This is called "Smart Governance".

Smart Governance has implications for the development of quality public services. The form of service provided to the community as a form of responsibility is carried out by centralizing integrated services. As a result of the system being able to support and guarantee effective services and easy access. Smart governance is the focus of the author's research because it is able to answer questions about what is the relationship between smart governance itself and the quality of public services in the future that will be able to create services that can be categorized as efficient and better, the best leadership, and how a public service activity can be carried out. Mobile and provide views to every government agency to make government policies through various innovations. Innovative public sector so that the community can provide feedback by participating.

The implementation of public service policies in Indonesia has become a strategic focus due to the improvement in the quality of government policies in this field that seems stagnant, even though the resulting impacts are spread to various fields and elements of life starting from the economic, cultural and socio-political side, as well as fields other [15]. The standardization of a service to the community is used as an indicator of the implementation of public services as well as a guide in the parameters for improving the quality of services which is the obligation of policy makers to provide services to the community by providing quality, fast, comfortable services, and access to receive these services is adequate and measurable, but all those dreams seemed to vanish like a false promise by seeing with naked eyes that the quality of service in Indonesia which is still convoluted, makes standardization of service quality in Indonesia far from effective, evidence of discrimination is the beginning of the destruction of a country's services.

The city of Makassar has begun to aggressively use ICT in running its government as a form of embodiment of a smart city. The beginning of the Movement Towards 100 Smart Cities was officially announced on May 22, 2017 by a combination of various government agencies, namely from the Kominfo, Ministry of Home Affairs, Ministry of PUPR, and also Bappenas. This support underlies the Dukcapil (Population and Civil Registry) Office of the Makassar City Government to take part in implementing a smart city through the concept of smart governance by launching a program as a form of embodiment of improving public services in the city of Makassar, namely the "Rindu Capil" or Online Queue program. The purpose of the implementation of Rindu Capil by Dukcapil of Makassar City Government as a waiting list for online services using a website basis. The implementation is that all services can be accessed by the public using the internet in opening a website to register. The public is given a choice for the next 14 days to schedule their visit and there are service options and a list of documents that need to be prepared based on the service choice regulations. This program is designed exclusively to make it easier for the public to monitor actual public services.

In accordance with the background that the author has explained, in order to carry out the research, the author is interested in conducting a study to find out the strategy implementation implemented smart governance by the Makassar City Dukcapil Service.

\section{LITERATURE REVIEW}

\subsection{Smart Governance}

Smart Governance is often used also to describe the activities involved "in new technologies combined with innovative strategic policies to achieve more resilient and superior governance structures and government infrastructure" [11]. Another opinion came from experts Mellouli, Luna 
Reyes and Zhang [16] who wrote that smart governance is the widespread use of technology by the government, which focuses on two important things, namely the movement to open data and technology everywhere, so that it can see the problem is what actually happens in the community so as to be able to build better relations between the government and its citizens, the state, private organizations, NGOs, and other governments.

Giffinger et al [10] suggests that smart governance divides several aspects, namely as a participant in political and administrative services for the community. Smart governance is the promotion of smart city initiatives. Then according to Walravens defines smart governance as the procedures taken in making decisions and the process of selecting implementation decisions that use network technology. [22]

Smart Governance according to Anthopaulus \& Reddick which explains that smart governance is part of a smart city that is devoted to discussing the ability of local governments to discuss the performance of local governments in providing services to the community. Smart governance can be interpreted as the application of technology and information in improving the quality of decision making government policies and collaborative governance. [3]

\subsubsection{Desired Results of Smart Governance}

Meijer and Bolivar [7] share some of the desired outcomes of smart governance, namely:

First, several authors underline the influence of smart governance on the economic increasing of cities. Kourtit, Nijkamp, and Arribas [12] and Batagan [5], for example, show that smart governance helps drive the city's economic performance grows as expected in the improvement of public service to citizen.

Second, many researchers define and conclude that public services are the ideals of government. Batagan, for example, points out that smart governance is collaboration between departments and with communities to make services truly citizen-centred. [5]

Third, the disconnection of social relations by the community is a problem that is often found in urban areas. This makes the government feel pressured because it is required to make and improve policies that provide access and provide the same facilities to provide greater benefits in improving living standards. These policies have been carried out with the topic "Smart governance" with the goal of achieving social equity for all urban residents in public services.

Fourth, the improvement of an environmentally friendly system is one of the expectations of the impact of smart governance. In this case, Batagan think that "smart systems represent fully support in the context of urban development, that result in build a sustainable city". [5]
Fifth, several authors reveal "e-governance the ability of government institutions that become references to interact with the public online in carrying out public services and fulfilling the mandates that have been established" [17]. Smart governance is always considered part of the new innovation that is used to "e-democracy". [11]

Sixth, several authors point out that branding city is the main outcome sought from smart governance. In this case, shows the concept of "smart governance" is just a label related to the managerial competence of city government to show the intelligence of life in the city [6]. Point out that "local governments only aim to get a better position in the ranking of cities by ignoring their objectives and effective in making strategic plans". Therefore, improving the image of the city is another expected result of smart governance. [10]

Seventh, the main ambition of smart city planning is to make better use of available resources: efficient governance, systems Smart governance helps regulate and provide efficiency in implementing community services [6]. Intelligence in the management system has a positive effect on administrative functions. [10]

Eighth, Smart governance has the goal of increasing the number of citizens with higher education in cities. Smart cities aim to become centers of higher education. People who pursue higher education are likened to someone who plays an important role in the growth of smart cities, and therefore smart governance aims to strengthen this process. [24]

Ninth, the expected final result is preparedness for disaster management. The system should always be available. In the face of a disaster, cities are required to respond quickly to emergency conditions and manage balanced risks. [1]

These results can be categorized into (1) firstorder results or improvements in the government system so as to implement efficient and effective policies, including disaster mitigation preparedness; (2) second-order outcomes or changes in government positions vis-a-vis other urban actors (community-centred services, community-based relationships, and strong citizen brands); and (3) third-level or urban development outcomes covering a growing economy, social inclusion, ecological performance and community education.

\subsubsection{Implementation Strategy to Realize Smart Governance}

Based on the analysis of Meijer and Bolivar, identify implementation strategies to realize smart 
governance as follows: [7]

a. Legislation is a key aspect for smart cities. In this regard, "what is needed not only for cities but also for governance and governance at every level is a new framework that takes into account the broad access to information that contemporary citizenship makes possible". In smart cities, "ICTs will be central, but so will issues of responsibility, openness, transparency, access to public data and the regulations that additional national government agencies may impose on what and how and where and why citizens can affect their municipal governance". [6]

b. Policies to promote smart city initiatives and projects are seen as important for smart city implementation. Several authors point out that the best governance is to promote smart city initiation. Governments in smart cities should promote policies oriented towards strengthening innovation systems, specifically focusing on knowledge that may be more fundamental, and on cultural development needs to be developed, carefully constructed by the governing authorities. [13]

c. Use of ICT for municipal government. According to Batty et al, the first major change in the context of smart cities is the development of information infrastructure that sustains cities through distributed computing and networks that are available to everyone with a device that can access the infrastructure. The fact that such an infrastructure is now available requires coordination in order for services to be delivered effectively [6]. Within this framework, the government plays a dual role in promoting smart cities. On the one hand, the city government must carry out a city service transformation project that must operate in order to achieve certain policy objectives (implementation processes) and organizational goals (decisionmaking) [22]. To achieve this goal, the system smart governance must enable collecting data and information related to public management with a network of instruments. On the other hand, the government must also support the development of technology and service models in Smart City. [2]

d. An integral vision for the smart city is seen as essential for its proper realization. Previous research has shown that smart governance is a much more powerful function of intelligence to coordinate the various components that make up a smart city. Smart governance is a collection of principles, factors and competencies that are the elements that make up governance that has the capacity to solve problems and interests of the community [23]. In smart governance systems, government remains a mechanism for collective action, but often, "as organizers and advocates rather than the first movers of society". [14] e. The final aspect of implementation is collaborative governance. Smart cities need smart systems to enhance collaboration between departments and with communities. "Smart governance is an arrangement that utilizes community-based innovation and connectivity that utilizes technological developments is a smart strategy" [21]. Therefore, smart governance is the activity of coordinating communication to achieve common goals through collaboration. [23]

This review highlights two main aspects of implementing strategies for realizing smart governance: ideas and actions. The integral vision of the city is a guiding idea, and this translates into legal, technological, policy and collaborative action. This implementation requires action in different but interrelated domains guided by an overarching perspective on smart governance.

\subsection{Miss Capil}

Capil Missis a policy issued by the Dukcapil Office of Makassar City as a form of concern for improving services to residents.

Today, policy makers in Indonesia have tried and made emergency efforts in order to improve the country's economic sector and continue to run. The government's job is to provide public services online. In addition to support industry 4.0 changes, the government should make policies to improve and enhance competitive competition and strive to become superior.

In Indonesia, the implementation of public services is a strategic policy theme because there is no improvement in providing public services to the community, even though the impact of this can be widespread. This is because the scope of community life in the economic, social, political, cultural, and other sectors is touched by public services. [15]

The fact is that the implementation of public services carried out both at the central and regional levels is still not efficient and effective, both in terms of service quality and human resources are not qualified. This fact is obtained from the frequent complaints and complaints made by the public, in which the community demands that public services be provided better and whose improved quality is.

Responding to complaints submitted by the community as users of the service. Dukcapil Regarding the queue of public services that take a 
long time in service delivery, this is a benchmark for implementing smart governance. One of the causes of community dissatisfaction with the services provided is that people have to queue for a long time. The application of Smart Governance in public services itself in Makassar City is very much.

Miss capil came to answer these complaints. This policy, called Rindu capil, was used at the beginning of the inauguration for the people of Makassar City in 2019. Rindu Capil is a policy where people can queue online through the web provided, by opening the website they can register online. The public can arrange their attendance within 14 days and the types of services and information on file requirements are provided in accordance with the services needed. The Miss Capil program is also designed in real time and can be seen by the public when accessing the web so that the remaining queues to be served can be known. Thus, people can adjust their attendance time to the queue number they get so they can measure their arrival so they don't have to wait long.

Then for people who don't understand how to access the Rindu Capil web, the Makassar City Disdukcapil has prepared officers to direct and provide assistance so that people can take advantage of the website. There are around 600 queues at the Makassar City Disdukcapil per day and can be accessed through the www.dukcnapilmakassar.co.id page.

\section{RESEARCH METHODS}

The author conducted this research in the period from September to October 2021. The location of this research is at the Makassar City Dukcapil Office and the Service Kominfo Makassar.

The research method used is qualitative with descriptive type which is not hypothesis testing but to describe related to the strategic implementation of smart governance. Research focus leads to strategy implementation smart governance that has been carried out in the service sector. The success rate of the smart governance strategy is obtained by looking at three aspects, namely the use of technology, vision, and collaboration.

The information needed in the research carried out was obtained directly from the Head of Service Innovation of the Dukcapil Service, Information Systems Analysts, Data Managers of the Innovation Section, and the community, as well as from the City Communication and Information Office

Makassar there were two informants namely the Head of Broadcasting and Media Partnerships Section, and
Staff Applications and Telematics. The data collection was carried out using the interview method, observing (observation), and documents obtained from informants who had a relationship with the problems formulated in the research carried out.

In this study, data sources were used from primary data that had been collected and obtained directly from informants or their initial origin. Furthermore, data from interviews, observations, and documentation and secondary data are generated from existing sources, and the review process is from literature, government regulations, study materials, files obtained from places that the authors examine. Meanwhile, within the framework of the data, three triangulations were carried out, namely source triangulation, time triangulation and technical triangulation.

\section{RESULTS AND DISCUSSION}

\subsection{Smart Governance Implementation Strategy in Makassar City (Case Study on Miss Capil Program)}

\subsubsection{Use of Technology}

The first thing that is important to develop in the smart city concept is the construction of an information infrastructure that supports cities through distributed computing and networks that are available to everyone with devices that can access the infrastructure. The reality is that such infrastructure is now available and requires synergy in order to provide optimal public services.

Based on the results of research on the use of technology at the Dukcapil Office of Makassar City to apply smart governance to provide services, it can be considered effective because of the miss capil program which is a breakthrough to reduce long queues when providing services. This program helps the community to get more efficient and effective services because people can get a queue number even at home, meaning this program makes it easy for the community to get a queue number. The Miss Capil program is an application to take queues online based on a website for the people of Makassar City. On the website, the public can choose their attendance schedule within a span of 14 days and has provided the types of services that can be selected according to their needs along with information on the requirements for service requests selected. The Miss Capil 
program is also designed in real time so that people can get queue numbers, people can see queue numbers directly through a real time system so they can find out people who have not been served, then are able to adjust the time with the queue numbers obtained in order to measure their arrival at the location so that no need to wait long and more efficient. This proves that the Dukcapil Office of Makassar City pays attention to the source of the community's problems, considering that people are now good at judging whether an agency is good or not in providing services, whether or not they have been served for a long time.

\subsubsection{Vision}

A integrated vision in implementing smart cities is important to be realized properly. Previous research has shown that smart governance is an intelligence competency with a much better capacity to coordinate all elements that support smart cities. Several components such as principles, factors and competencies are elements that make up governance that has the capacity to solve problems and interests of the community [23]. In smart governance, governments are obliged to make collective policies and structured actions, but oftentimes, "as organizers and advocates rather than the first movers of society". [14]

Based on the results of research related to the vision that is used as the direction of achieving the goals to be achieved, namely the vision that reads "Makassar towards orderly ownership and civil registration", to achieve this it is necessary to build a strategic plan to make that dream come true. The real proof of strategic plan designed to achieve mission the is to innovate. Innovation is seen as a strategic way to make an organization able to compete in the current era of globalization. Every agency in the city of Makassar is required to make breakthroughs to support Makassar as a smart city. The steps taken are to make Makassar a smart governance. Smart Governance can be realized by creating innovations by utilizing the current state of technology.

This has been carried out by the Dukcapil Office of the Makassar City Government by launching an idea in the form of program output by utilizing technology as the main key, one of which is the miss capil program. Miss capil or online queues are an answer to the demands of the community regarding service delivery and also as a realization of the vision that has been the aspiration of the community and government.

\subsubsection{Collaborative}

The final aspect of implementation is collaborative governance. Smart cities need smart systems to enhance collaboration between departments and with communities. "Smart governance is leveraging community-based innovation and connectivity utilizing technological developments is strategy a smart" [21]. Therefore, smart governance is the activity of coordinating communication to achieve common goals through collaboration [23]. The aspect collaborative is a very important indicator to realize a city into smart governance to be named a smart city.

Based on the results of research on cooperation, the authors found that this strategy has been implemented effectively by the Dukcapil of Makassar City by collaborating with the Makassar City Communication and Information Office. This collaboration is carried out because the Diskominfo is a server for providing network to Disdukcapil, the network speed provided by the server (Diskominfo) is considered very helpful in accelerating the service acceleration process at Disdukcapil because the resulting network speed is able to provide satisfactory results when the Miss Capil program is run. Collaboration from the government, namely with PT. Telkom and for collaboration from the private sector, namely Lintasarta, although it is not directly related to the Disdukcapil party, it is directly related to the Diskominfo party.

However, the problem here is that the collaboration between Disdukcapil and the community itself has not been effective, this is because community participation related to this program is still relatively low for various reasons including online-based services which are considered too complicated and there are still many people who are technology stuttering and other problems are still there are people who don't have an android phone so they can't apply the program.

\section{CONCLUSION}

\subsection{Conclusion}

(1) The use of technology at the Dukcapil Office of Makassar City to be one of the agencies that implement the Civil Service Missing smart governance in providing services can already be considered effective, as evidenced by the program which is a breakthrough to reduce long queues when providing services. (2) The vision aspect has also been fairly effective, we can see this with the launch of innovations by the Dukcapil of Makassar City by utilizing technology, one of which is the 
miss capil program. Missing capil or online queues is considered to be the answer to the vision that has been used as a goal by the Office Population Registry Makassar Cityand Civil. (3) The aspect collaborative has not been fully considered effective, although cooperation between government and private organizations has been established, but community participation related to this program is still low.

Seeing the current situation where every agency is required to innovate innovations to support Makassar as a smart city, then each agency must also conduct socialization special to the Population Makassar City and Civil Registry Office on programs issued to the public so that the program can run as it should, because we know that these innovations have the effect of providing public services that meet the expectations of the community.

\section{REFERENCES}

[1] Alkandari, A., Alnasheet, M., \& Al shekhly, IF, "Smart cities: Survey". Journal of Advanced Computer Science and Technology Research, 2012. 2, 79-90.

[2] AM ETIC, "Smart cities. Madrid, Spain: Lea ders Comun icacion", 2013.

[3] Anthopoulos, LG, \& Reddick, CG, "Smart C ity and Smart Government". In Proceedings of the 25th international conference companion on world wide web WWW'16, 2016. (pp. $351-$ $355)$.

[4] Barrionuevo, JM, Berrone, P., \& Ric art, JE, "Smart Cities, Sustainable Progress". IESE Insight, 2012. 14, 50-57.

[5] Batagan, L, "Smart Cities And Sustainability Models". Informatica Economica", 2011. 15, 80-87.

[6] Batty, M., Axhausen, KW, Giannotti, F., Pozdnoukhov, A., Bazzani, A., Wachowicz, M., Portugali, Y, "Smart cities of the future". European Physical Journal, 2012. 214, 481518.

[7] Bolivar, MPR, \& Meijer, AJ, "Smart Governance: Using a Literature Review and Empirical Analysis to Build a Research Model". Social Science Computer Review, 2016. 34(6), 673-692.

[8] Caragliu, A., De 1 Bo, C., \& Ni jkamp, P, "Smart citis in Europe". Proceedings to the 3rd
Central European Conference on Regional Science, Kosice, Slovak Republic, 2009. $45-59$.

[9] Cohen, B, "The Top 10 Smart Cities On The Planet". 2012.

[10] Giffinge, R., \& Pichle r-Milanovi'c, N, "Smart cities: Ranking of European medium-size d cities". Centre of Regional Science, Vienna University of Technology, 2007.

[11] Giffinger, R., Fertner, C., Kramar, H., Meijers, E., \& Pichler-Milanovic', N, "Smart cities: Ranking of European medium-sized cities". Vienna, Austria, 2007. Retrieved from http://www.smartcities.eu/download/smart_cities_final_rep ort .pdf.

[11] Gil-Garcia, JR, Helbig, N., \& Ojo, A, "Being smart: Emerging technologies and innovationn in the public sector". Government Information Quarterly, 31 (supplement 1), 2014. I1-I8.

[12] Kourtit, K., Nijkam p, P., \& Arribas, D, "Smart Cities In Perspective A Comparative European Study Bymeans Of Self-Organizing Maps". Innovation: The European Journal of Social Science Research, 2012. 25,229-246.

[13] Leydesdorff, L., \& Deakin, M, “TripleHelix Model Of Smart Cities: A NeoEvolutionary Perspective". Journal of Urban Technology, 2011. 18, 53-63.

[14] Linders, D, "From E-Government To WeGovernment: Defining A Typology For Citizen Coproduction In The Age Of Social Media". Government Information Quarterly, 2012.29, 446-454.

[15] Mahsyar, A, "Masala h Pelayanan Publik di Indonesia dalam Perspektif Administrasi Publik". Otoritas Jurnal Ilmu Pemerintahan, 2011. 1(2)

[16] Mellouli, S., Luna-Reye s, LF, \& Zhang, J. (2014), "Smart government, citizen participation and open data". Information Polity, 19 (1, 2), 2014. 1-4.

[17] Odendaal, N, "Information And 
Communication Technology And Local Governance: Understanding The Difference Between Cities In Developd And Emerging Economies". Computer s, Environmen t and Urba n System s, 2003. 27, 585-607.

[18] Power, A, "Poor areas and social exclusion". Paper Presented at the CA SE/L SE Housing Seminar on "Social Exclusion and the Future of Cities. 1999.

[19] Scytl, "Smart Governance For Smart Cities", 2015. Setiawan, H, "Metode Audit Tata Kelola Teknologi, 2013.

[20] Supangkat, SH, "Essay Smart City Development in Indonesia and Asian Africa Nations. IEIC E Global Plaza No.78, 2015.

[21] Tapscott, D., \& Agnew, D, "Governance in the Digital Economy". The Importance of Human Development. Finance \& Development, 1999. 36, 34-37.

[22] Walravens, N, "Mobile Business and the Smart City: Developing A Business Model Framework to Include Public Design Parameters for Mobile City Services". Journal of Theoretical and Applied Electronic Commerce Research, 2012. 7, 121-135.

[23] Willke, H, "Smart Governance: Governing The Global Knowledge Society". New York, NY: Campus Verlag, 2007.

[24] Winters , JV, "Why Are Smart Cities Growing? Who Moves and Who Stays. Journal of Regional Science, 2011. 51, 253-270. 